Prepared in cooperation with the City of Boise

Mercury Concentrations in Water, and Mercury and Selenium Concentrations in Fish from Brownlee Reservoir and Selected Sites in Boise and Snake Rivers, Idaho and Oregon, 2013

Open-File Report 2014-1099 



\title{
Mercury Concentrations in Water, and Mercury and Selenium Concentrations in Fish from Brownlee Reservoir and Selected Sites in Boise and Snake Rivers, Idaho and Oregon, 2013
}

\author{
By Dorene E. MacCoy
}

Prepared in cooperation with the City of Boise

Open-File Report 2014-1099 


\section{U.S. Department of the Interior \\ SALLY JEWELL, Secretary}

\section{U.S. Geological Survey \\ Suzette M. Kimball, Acting Director}

U.S. Geological Survey, Reston, Virginia: 2014

For more information on the USGS-the Federal source for science about the Earth,

its natural and living resources, natural hazards, and the environment-visit

http://www.usgs.gov or call 1-888-ASK-USGS

For an overview of USGS information products, including maps, imagery, and publications, visit $h$ ttp://www.usgs.gov/pubprod

To order this and other USGS information products, visit http://store.usgs.gov

Suggested citation:

MacCoy, D.E., 2014, Mercury concentrations in water, and mercury and selenium concentrations in fish from Brownlee Reservoir and selected sites in Boise and Snake Rivers, Idaho and Oregon, 2013: U.S. Geological Survey Open-File Report 2014-1099, 26 p., http://dx.doi.org/10.3133/ofr20141099.

ISSN 2331-1258 (online)

Any use of trade, firm, or product names is for descriptive purposes only and does not imply endorsement by the U.S. Government.

Although this information product, for the most part, is in the public domain, it also may contain copyrighted materials as noted in the text. Permission to reproduce copyrighted items must be secured from the copyright owner. 


\section{Contents}

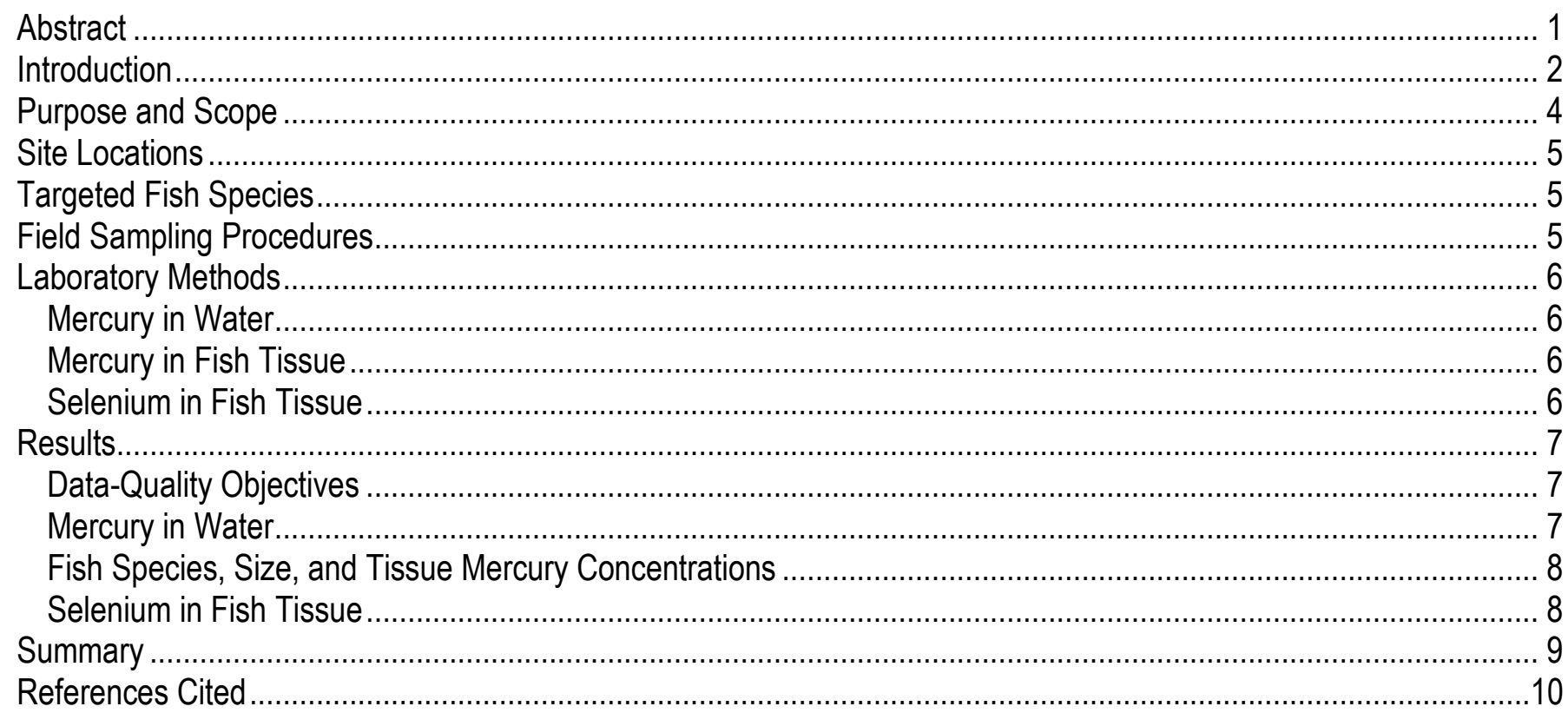

\section{Figures}

Figure 1. Map showing location of sites where water and fish tissue samples were collected for analysis of total mercury and selenium, Idaho and Oregon, October 2013

Figure 2. Photographs of channel catfish $(A)$ and smallmouth bass $(B)$ at the Snake River near Murphy sampling site, October 2013

Figure 3. Boxplot showing total mercury concentrations in fish tissue collected from sites in the Boise and Snake Rivers and Brownlee Reservoir, October 2013, Idaho and Oregon.

Figure 4. Graphs showing total mercury tissue concentrations and total length of mountain whitefish $(A)$, smallmouth bass $(B)$ and channel catfish $(C)$ in samples from the Boise and Snake Rivers and Brownlee Reservoir, Idaho and Oregon, October 2013.

\section{Tables}

Table 1. Sites in the Boise and Snake Rivers and Brownlee Reservoir where water and fish samples were collected for mercury analysis, Idaho and Oregon, 2013

Table 2. Targeted fish species in the Boise and Snake Rivers and Brownlee Reservoir, Idaho and Oregon............. 18

Table 3. Quality-control sample results for analysis of total mercury in fish from the Boise and Snake Rivers and Brownlee Reservoir, Idaho and Oregon, October 2013

Table 4. Total mercury concentrations in water from the Boise and Snake Rivers and Brownlee Reservoir, and associated field blanks and laboratory matrix spike recovery for samples collected in October and November 2013

Table 5. Individual sport fish tissue total mercury concentrations, fish size data, and statistical site summaries in samples collected from the Boise and Snake Rivers and Brownlee Reservoir, Idaho and Oregon, October 2013..... 22 Table 6. Selenium concentrations in individual sport fish tissue collected from the Boise and Snake Rivers and Brownlee Reservoir, Idaho and Oregon, October 2013 


\section{Conversion Factors and Datum}

\section{Conversion Factors}

SI to Inch/Pound

\begin{tabular}{lll}
\hline & Multiply & \\
\hline & Length & To obtain \\
\hline centimeter $(\mathrm{cm})$ & 0.3937 & inch (in.) \\
millimeter $(\mathrm{mm})$ & 0.03937 & inch (in.) \\
\hline & Volume & \\
\hline milliliter $(\mathrm{mL})$ & 0.03381 & ounce, fluid (fl. oz) \\
\hline & Mass & \\
\hline gram $(\mathrm{g})$ & 0.03527 & ounce, avoirdupois (oz) \\
kilogram $(\mathrm{kg})$ & 2.205 & pound avoirdupois (lb) \\
milligram $(\mathrm{mg})$ & 0.000035 & ounce, avoirdupois (oz) \\
nanogram $(\mathrm{ng})$ & $3.5 \times 10^{-11}$ & ounce, avoirdupois (oz) \\
\hline
\end{tabular}

Concentrations of chemical constituents in water are given in micrograms per liter ( $\mu \mathrm{g} / \mathrm{L})$, equivalent to part per billion; nanograms per liter (ng/L), equivalent to part per trillion; nanograms per gram $(\mathrm{ng} / \mathrm{g})$, equivalent to part per billion; and milligrams per kilogram $(\mathrm{mg} / \mathrm{kg})$, equivalent to part per million.

\section{Datum}

Horizontal coordinate information is referenced to the North American Datum of 1983 (NAD 83). 


\title{
Mercury Concentrations in Water, and Mercury and Selenium Concentrations in Fish from Brownlee Reservoir and Selected Sites in Boise and Snake Rivers, Idaho and Oregon, 2013
}

By Dorene E. MacCoy

\begin{abstract}
Mercury $(\mathrm{Hg})$ analyses were conducted on samples of sport fish and water collected from six sampling sites in the Boise and Snake Rivers, and Brownlee Reservoir to meet National Pollution Discharge and Elimination System (NPDES) permit requirements for the City of Boise, Idaho. A water sample was collected from each site during October and November 2013 by the City of Boise personnel and was analyzed by the Boise City Public Works Water Quality Laboratory. Total Hg concentrations in unfiltered water samples ranged from 0.73 to 1.21 nanograms per liter (ng/L) at five river sites; total $\mathrm{Hg}$ concentration was highest $(8.78 \mathrm{ng} / \mathrm{L})$ in a water sample from Brownlee Reservoir. $\mathrm{All} \mathrm{Hg}$ concentrations in water samples were less than the EPA $\mathrm{Hg}$ chronic aquatic life criterion in Idaho $(12 \mathrm{ng} / \mathrm{L})$.

The EPA recommended a water-quality criterion of 0.30 milligrams per kilogram $(\mathrm{mg} / \mathrm{kg})$ methylmercury ( $\mathrm{MeHg}$ ) expressed as a fish-tissue residue value (wet-weight $\mathrm{MeHg}$ in fish tissue). $\mathrm{MeHg}$ residue in fish tissue is considered to be equivalent to total $\mathrm{Hg}$ in fish muscle tissue and is referred to as $\mathrm{Hg}$ in this report. The Idaho Department of Environmental Quality adopted the EPA's fish-tissue criterion and a reasonable potential to exceed (RPTE) threshold 20 percent lower than the criterion or greater than $0.24 \mathrm{mg} / \mathrm{kg}$ based on an average concentration of 10 fish from a receiving waterbody. NPDES permitted discharge to waters with fish having $\mathrm{Hg}$ concentrations exceeding 0.24 $\mathrm{mg} / \mathrm{kg}$ are said to have a reasonable potential to exceed the water-quality criterion and thus are subject to additional permit obligations, such as requirements for increased monitoring and the development of a Hg minimization plan. The Idaho Fish Consumption Advisory Program (IFCAP) issues fish advisories to protect general and sensitive populations of fish consumers and has developed an action level of 0.22 $\mathrm{mg} / \mathrm{kg}$ wet weight $\mathrm{Hg}$ in fish tissue. Fish consumption advisories are water body- and species-specific and are used to advise of allowable fish consumption from specific water bodies. The geometric mean $\mathrm{Hg}$ concentration of 10 fish of a single species collected from a single water body (lake or stream) in Idaho is compared to the action level to determine if a fish consumption advisory should be issued.
\end{abstract}


The U.S. Geological Survey collected and analyzed individual fillets of mountain whitefish (Prosopium williamsoni), smallmouth bass (Micropterus dolomieu), and channel catfish (Ictalurus punctatus) for $\mathrm{Hg}$. The median $\mathrm{Hg}$ concentration of $0.32 \mathrm{mg} / \mathrm{kg}$ exceeded the Idaho water-quality criterion at the site in Brownlee Reservoir. Average Hg concentrations from Brownlee Reservoir (0.32 $\mathrm{mg} / \mathrm{kg})$ and the Boise River at mouth $(0.33 \mathrm{mg} / \mathrm{kg})$ exceeded the Hg RPTE threshold $(>0.24 \mathrm{mg} / \mathrm{kg})$. IFCAP action levels also were exceeded at the sites on Brownlee Reservoir and at the mouth of the Boise River. Median Hg concentrations in fish at the remaining four river sites were less than 0.20 $\mathrm{mg} / \mathrm{kg}$ with average concentrations ranging from 0.14 to $0.21 \mathrm{mg} / \mathrm{kg} \mathrm{Hg}$.

Selenium (Se) analysis also was conducted on one composite fish tissue sample per site to screen for general concentrations and to provide information for future risk assessments. Concentrations of Se ranged from 0.07 to $0.49 \mathrm{mg} / \mathrm{kg}$ wet weight; average concentrations were highest in smallmouth bass $(0.40 \mathrm{mg} / \mathrm{kg})$ and lowest in mountain whitefish $(0.12 \mathrm{mg} / \mathrm{kg})$.

\section{Introduction}

Mercury $(\mathrm{Hg})$ is a global pollutant that ultimately makes its way into every aquatic ecosystem through the hydrologic cycle. Atmospheric deposition of inorganic $\mathrm{Hg}$ contributes the vast majority of $\mathrm{Hg}$ to aquatic systems, although geologic sources and point-source pollution also may contribute to $\mathrm{Hg}$ loading. Once it is in aquatic systems, inorganic $\mathrm{Hg}$ may become methylated through microbial sulfate reduction (Fitzgerald and Lamborg, 2007). Methylmercury ( $\mathrm{MeHg}$ ) is by far the more bioavailable and toxic form of $\mathrm{Hg}$; and, once $\mathrm{Hg}$ has moved through aquatic food chains into predatory fish, almost all $\mathrm{Hg}$ present in fish tissue is MeHg. In turn, sport fish that are most commonly caught and consumed by subsistence or recreational anglers tend to be predatory fish. As a result of these dynamics, risks of $\mathrm{MeHg}$ exposure to humans are almost exclusively through consumption of fish (U.S. Environmental Protection Agency, 2001).

The U.S. Environmental Protection Agency (EPA) recommended water-quality criterion for $\mathrm{MeHg}$ is expressed as a fish-tissue residue value (wet-weight $\mathrm{MeHg}$ in fish tissue). The MeHg criterion is based on fresh weight, appropriately reflecting the nature of fish destined for human consumption. The Idaho Department of Environmental Quality (IDEQ) adopted EPA's fish-tissue criterion as the Idaho $\mathrm{MeHg}$ water-quality criterion and published implementation guidance for the Idaho $\mathrm{Hg}$ waterquality standard (Idaho Department of Environmental Quality, 2005). The criterion of 0.3 milligram MeHg per kilogram $(\mathrm{mg} / \mathrm{kg})$ of wet weight fish is based on protecting an adult consumer who eats an average of $17.5 \mathrm{~g}$ of fish per day - this is equivalent to about one, 8-ounce serving every other week (U.S. Environmental Protection Agency, 2001; Idaho Department of Environmental Quality, 2005). Total $\mathrm{Hg}$ is analyzed in place of $\mathrm{MeHg}$ in fish tissue for two reasons: (1) total $\mathrm{Hg}$ is easier and less costly for laboratories to determine than $\mathrm{MeHg}$, and (2) nearly all $\mathrm{Hg}$ present in fish muscle tissue is MeHg (Bloom, 1992; Hammerschmidt and others, 1999; Harris and others, 2003). Interpretation of total $\mathrm{Hg}$ analysis as $\mathrm{MeHg}$ will likely bias high the results as $\mathrm{MeHg}$ in fish on the order of less than 1.011.05 based on comparisons shown by Bloom (1992) and by Hammerschmidt and others (1999). This magnitude of potential bias is well within the range of expected analytical variability. In comparing fishtissue results with the criterion, the analytical results for total $\mathrm{Hg}$ in the fish tissue should be interpreted as 100 percent $\mathrm{MeHg}$. For the remainder of this report, total $\mathrm{Hg}$ analyzed in both water and fish tissue will be referred to as $\mathrm{Hg}$. 
The Idaho implementation guidance describes two scales of monitoring for $\mathrm{Hg}$ in fish tissue: (1) statewide ambient monitoring and (2) facility/source monitoring. The Idaho Statewide Ambient Monitoring Program was designed to monitor concentrations of $\mathrm{Hg}$ in fish tissue that represent an integrated exposure to Hg throughout a water body over time (Idaho Department of Environmental Quality, 2005). The Idaho Statewide Ambient Monitoring Program began collecting fish tissue in 2004 and was discontinued in 2009 because of funding constraints (Essig and Kosterman, 2008; Essig, 2010). The facility/source monitoring is targeted at potential local sources. The EPA Office of Wastewater Management in partnership with the State of Idaho manages the National Pollution Discharge and Elimination System (NPDES) to help track and manage permits for point-source dischargers (U.S. Environmental Protection Agency, 2012a). Certain NPDES permittees are required to analyze for $\mathrm{Hg}$ in effluent and in fish that inhabit the receiving waterbodies (Idaho Department of Environmental Quality, 2005).

The 2005 IDEQ implementation guidance document requires NPDES permittees to provide data for Hg in fish tissue under the Reasonable Potential To Exceed (RPTE) process (Idaho Department of Environmental Quality, 2005). The RPTE threshold is designed to protect people that consume fish and is based on an average $\mathrm{Hg}$ concentration from 10 fish not to exceed 80 percent of the $0.3 \mathrm{mg} / \mathrm{kg}$ Idaho criterion or greater than $0.24 \mathrm{mg} / \mathrm{kg}$ wet weight $\mathrm{Hg}$ in fish from the receiving water body. The IDEQ guidance recommends additional pollution prevention and sampling actions if the RPTE threshold is exceeded. The EPA has included numerical $\mathrm{Hg}$ limitations, $\mathrm{Hg}$ minimization plan development, watershed based fish tissue and water $\mathrm{Hg}$ sampling, and annual reporting requirements in the City of Boise's two effluent permits for the Lander Street and the West Boise Wastewater Treatment Facilities (U.S. Environmental Protection Agency, 2012b, 2012c).

The Idaho Fish Consumption Advisory Program (IFCAP) issues fish advisories to protect fish consumers and has developed an action level of $0.22 \mathrm{mg} / \mathrm{kg}$ wet weight $\mathrm{Hg}$ in fish tissue. Fish consumption advisories are water body- and species-specific and are used to advise general and sensitive populations of the allowable consumption of fish obtained from Idaho waters. The geometric mean $\mathrm{Hg}$ concentration of 10 fish of a single species collected from a single water body (lake or stream) in Idaho is compared to the action level to determine if a consumption advisory should be issued.

EPA considers a total recoverable mercury concentration of $12 \mathrm{ng} / \mathrm{L}$ to be the effective chronic aquatic life criterion in Idaho for the purposes of the Clear Water Act (Idaho Department of Environmental Quality, 2014, referred to as EPA aquatic life criteria in this report). The City of Boise's NPDES permits require a minimum detection level for $\mathrm{Hg}$ of $0.5 \mathrm{ng} / \mathrm{L}$, sufficiently low enough to compare to EPA criteria. 
The implicit purpose of collecting data on $\mathrm{Hg}$ in water and fish tissue at the same location is to facilitate developing fish bioaccumulation factors, which are ratios of tissue and water $\mathrm{Hg}$ concentrations. Bioaccumulation factors (BAFs) can be useful for water-quality management, such as site-specific implementation targets of the fish-tissue based $\mathrm{MeHg}$ water-quality criteria, and total maximum daily load target development (Idaho Department of Environmental Quality, 2005; U.S. Environmental Protection Agency, 2010). For developing BAFs, it is not essential that the water and fish samples are collected at the same time. Riva-Murray and others (2012) reported that, in streams in Oregon and New York, the best BAF estimates came from sampling MeHg in water during the July to September growing season, regardless of when the fish were collected. In related analyses with fish, the optimal approach for estimating BAFs is to use $\mathrm{Hg}$ concentration data from at least 10 adult fish of a single species and similar length (Barbara Scudder Eikenberry, U.S. Geological Survey, written commun., 2013). BAFs are currently not calculated using the data published in this report. It is the intent that this data will be combined with future data-collection efforts for calculations of BAFs.

The City of Boise in cooperation with U,S. Geological Survey (USGS) developed a multiyear water and fish tissue Hg monitoring plan (Mebane and MacCoy, 2013) in the Snake and Boise Rivers and Brownlee Reservoir to satisfy the watershed based fish-tissue sampling requirements contained in the city permits. The IDEQ implementation guidance (Idaho Department of Environmental Quality, 2005) encourages municipal dischargers to establish monitoring cooperatives to help fund watershedbased statewide monitoring for $\mathrm{Hg}$ in fish tissue. The EPA further recommended that the permitting authority (which is the EPA in Idaho) require only one study per water body (U.S. Environmental Protection Agency, 2010). The multiyear water and fish tissue $\mathrm{Hg}$ monitoring plan (Mebane and MacCoy, 2013) was developed and intended to provide a framework for a cooperative Hg sampling program.

Although selenium (Se) analysis is not required for NPDES permit compliance, analysis of composite samples of fish tissue for Se was done to provide information for future risk assessments. The potential for $\mathrm{Hg}$ toxicity reduction in the presence of certain concentrations of Se has not been considered in fish consumption advisories or in comparing to criteria for the protection of human health but may be important in the future (U.S. Environment Protection Agency, 2001; Idaho Department of Environmental Quality, 2005).

\section{Purpose and Scope}

This report contains water-quality and fish-tissue data that meet the requirements of the first year (2013) of the implementation of the $\mathrm{Hg}$ monitoring plan in the Boise and Snake Rivers and Brownlee Reservoir (Mebane and MacCoy, 2013). The data contained in this report will provide a reference to which future determinations of $\mathrm{Hg}$ in water and fish can be compared.

This report contains $\mathrm{Hg}$ in water data collected by City of Boise personnel and $\mathrm{Hg}$ and $\mathrm{Se}$ in fish tissue collected by the USGS as described in the Hg monitoring plan (Mebane and MacCoy, 2013). Data collected by both agencies are reported here to meet the City of Boise NPDES permit requirements. Water samples and fish samples were collected at the same locations, near but not on the same dates. 


\section{Site Locations}

Six sampling sites (table 1) were selected to meet specific requirements for the City of Boise NPDES permits (U.S. Environmental Protection Agency, 2012b, 2012c). Site locations (fig. 1) were required to be upstream (Eckert) and downstream (Middleton) of the city's two wastewater facilities at Lander Street and West Boise on the Boise River, near the middle of the lower Boise River watershed (Middleton), at the mouth of the Boise River (Boise mouth), in the Snake River upstream (Murphy) and downstream (Nyssa) of the mouth of the Boise River, and in the impounded section of the Snake River downstream of the Boise River confluence (Brownlee). The site downstream of both wastewater facilities, Middleton, also was used to meet the middle of the lower Boise River watershed site requirement.

Information for multiple years of sampling is provided in the $\mathrm{Hg}$ monitoring plan (Mebane and MacCoy, 2013). In 2013, water and fish were collected at all six sampling sites (table 1, fig. 1). The sites were selected to meet specific NPDES requirements and to try to isolate the fish populations being sampled. There are no natural fish passage barriers between sampling sites to prevent fish migration. There are manmade diversions in the Boise River between Eckert and Middleton that act as fish passage barriers.

\section{Targeted Fish Species}

The targeted fish species were based on the Idaho Department of Environmental Quality (2005) recommendation that fish tissue samples should be representative of the $\mathrm{Hg}$ exposures likely encountered from recreational or subsistence fishing, and upon previous fish sampling at selected locations in the Boise and Snake Rivers and Brownlee Reservoir (table 2; Clark and Maret, 1998; Richter and Chandler, 2003; MacCoy, 2006).

Targeting specific fish species is inherently difficult because of fish movement and sample timing; the sampling crew in 2013 was fortunate to collect 10 individuals of a targeted fish species of edible size at each site. Sampling at Murphy provided an opportunity to collect samples of two targeted fish species, smallmouth bass and channel catfish. Smallmouth bass and channel catfish are important sport fish in the Snake River and these samples will provide a much needed comparison of Hg in fish tissue between species and sites (fig. 2).

\section{Field Sampling Procedures}

Water samples were collected by City of Boise personnel using low-level Hg surface-water sampling protocols (City of Boise, Public Works field standard operating procedures, written commun., March 12, 2014) following collection and quality-control procedures similar to those described in Lewis and Brigham (2004) and Essig (2010). Precleaned $200 \mathrm{~mL}$ glass bottles were used to collect dip water samples. Samples were placed on ice and delivered to the Boise City Public Works Water Quality Laboratory, within the same day. One field blank was used for quality control for each sampling site trip as described in Wilde (2006, section 4.3 "Quality-Control Samples"). 
Fish-tissue sampling was done during low-flow conditions to reduce hazards from maneuvering the boat or raft in high water velocities. Fish were captured by electrofishing; additional information on electrofishing sampling safety, sampling permit requirements, and justification for sampling outside the summer season is given in the Hg monitoring plan (Mebane and MacCoy, 2013).

Procedures for collecting and processing fish for analysis of $\mathrm{Hg}$ are similar to those outlined in Scudder and others (2008). Sampling procedures specific to this project are given here. Boat and raft electrofishing were used to collect targeted fish species at a site. Fish of edible size (greater than $25 \mathrm{~cm}$ in length, or for smallmouth bass, greater than $30 \mathrm{~cm}$ in length) were placed in a live well. When at least 10 individuals of the same species were collected, the fish were weighed, measured, euthanized, and placed in separate clean, clear, zip-seal bags on wet ice. Fish were transported to the sample preparation area at the USGS Idaho Water Science Center in Boise and processed within 24 hours to minimize possible loss of sample integrity. Two skinless fillets were obtained from each fish, one for the primary sample and the second retained frozen as a backup sample for $\mathrm{Hg}$ analysis. Approximately $5 \mathrm{~g}$ of tissue from each of the 10 fish collected from a site was composited for Se analysis. The backup samples were retained until data were received from the laboratory and reviewed. Fish-tissue samples for $\mathrm{Hg}$ analysis were shipped on dry ice to the USGS Mercury Research Laboratory (USGS MRL) in Middleton, Wisconsin. Fish-tissue samples for Se analysis were shipped on dry ice to the USGS National Water Quality Laboratory (NWQL) in Denver, Colorado.

\section{Laboratory Methods}

\section{Mercury in Water}

Unfiltered water samples were analyzed for $\mathrm{Hg}$ using laboratory methods consistent with EPA Method 1631 E (U.S. Environmental Protection Agency, Office of Water, 2002) by the Boise City Public Works Water Quality Laboratory. This method provided a minimum detection level of 0.2 ng/L.

\section{Mercury in Fish Tissue}

The USGS MRL provided analysis of $\mathrm{Hg}$ in fish tissue consistent with EPA Method 7473 (U.S. Environmental Protection Agency, 2007). This method provides a minimum detection limit of 0.005 $\mathrm{mg} / \mathrm{kg}$ dry weight, based on a $20-50 \mathrm{mg}$ sample size. The detection limit is sufficiently low to quantify $\mathrm{Hg}$ concentrations in fish tissue at less than $0.30 \mathrm{mg} / \mathrm{kg}$ wet weight. Additional USGS MRL qualityassurance procedures can be found on their website (U.S. Geological Survey, 2013).

\section{Selenium in Fish Tissue}

A sample size of less than $20 \mathrm{~g}$ is needed for Se analysis. The composite of a portion of tissue from each of 10 fish from a site resulted in a sufficient sample size. NWQL analysis of Se in tissue used methods by Garbarino and others (2006). This method provided a minimum level of detection of 0.1 $\mathrm{mg} / \mathrm{kg}$ dry weight. The Hg monitoring plan (Mebane and MacCoy, 2013) specified a composite of at least three fish per site. The composite of 10 fish provided a more than adequate sample for general Se screening. 


\section{Results}

\section{Data-Quality Objectives}

All data-quality objectives were met for this study and provide reliable $\mathrm{Hg}$ concentrations in water and in fish-tissue data collected from the Snake and Boise Rivers and Brownlee Reservoir. The data-quality objectives of this monitoring study are listed here:

1. The fish collected represent the species and size ranges likely to be caught and consumed by recreational or subsistence anglers in the vicinity of the sampling sites.

2. Sample processing, handling, storing, and shipping to the laboratory used sufficient qualityassurance measures to avoid introducing sample contamination or bias to the data.

3. Laboratory analytical techniques had sufficiently low detection limits to quantify $\mathrm{Hg}$ concentrations in fish tissue at less than $0.24 \mathrm{mg} / \mathrm{kg}$ wet weight (Idaho RPTE threshold).

4. Quality-control samples were analyzed to provide accuracy and precision information for the fish-tissue samples collected (table 3). The accuracy of the data was within 20 percent of the most probable value for certified reference tissues for $\mathrm{Hg}$, and the precision (repeatability) of the data was within 20 percent relative standard deviation in laboratory replicate analyses.

5. Following review, fish-tissue data were made available to the public and environmental management agencies through the online USGS National Water Information System (NWIS) and in this report.

6. Mercury concentrations in water quality-control samples are presented with the water sample results (table 4) and include field blanks for each site and laboratory matrix spikes. $\mathrm{Hg}$ concentrations in all but one field blank were less than or equal to the laboratory detection limit $(0.2 \mathrm{ng} / \mathrm{L})$. Matrix spike recovery of $\mathrm{Hg}$ in water samples ranged from 96.5 to 100.5 percent, well within the required recovery of 71-125 percent of the theoretical value. The relative percent difference of matrix spike duplicates required by EPA is less than 24 percent (U.S. Environmental Protection Agency, Office of Water, 2002).The observed relative percent difference of the matrix spike recovery was zero at two significant figures.

\section{Mercury in Water}

$\mathrm{Hg}$ in water was collected at all six sampling sites on the Boise and Snake Rivers and Brownlee Reservoir. Hg concentrations, field blank concentrations, and laboratory matrix spike recovery data are shown in table 4 . Concentrations of $\mathrm{Hg}$ in water were between 0.73 and $8.78 \mathrm{ng} / \mathrm{L}$ with the highest concentration from Brownlee Reservoir. All samples were less than the EPA aquatic life criteria (12 ng/L, Idaho Department of Water Quality, 2014). All field blanks were near or less than the detection level except for the sample taken at the Boise mouth site (detection of $0.70 \mathrm{ng} / \mathrm{L} \mathrm{Hg}$ ). The blank values, as well as the laboratory spike recovery, were within data-quality objectives. 


\section{Fish Species, Size, and Tissue Mercury Concentrations}

The concentration of $\mathrm{Hg}$ in fish tissue, as well as the length and weight of the fish collected from the Boise and Snake Rivers and Brownlee Reservoir in October 2013, are shown in table 5. A graphical summary of $\mathrm{Hg}$ concentrations in all fish from all sites is shown in figure 3 and summaries of individual fish length and $\mathrm{Hg}$ concentrations are shown in figure 4. All fish-tissue data presented in this report can be accessed on the USGS NWIS website (U.S. Geological Survey, 2014). Although this study was not designed to compare fish size to $\mathrm{Hg}$ concentration, graphical summaries of fish size and $\mathrm{Hg}$ concentration are presented, as they may be useful for fish advisory development.

Mountain whitefish were collected at the upstream site (Eckert) and at the downstream site (Middleton) of the City of Boise wastewater facilities on the Boise River (fig. 1). Total fish lengths were between 260 and $450 \mathrm{~mm}$ with the larger fish sampled from Eckert (fig. 4A). Median $\mathrm{Hg}$ concentrations in mountain whitefish were 0.18 and $0.17 \mathrm{mg} / \mathrm{kg}$ at Eckert and Middleton, respectively. Concentrations did not exceed the Idaho water-quality criterion, RPTE threshold level, or the IFCAP action level (table 5, fig. 3).

Smallmouth bass were collected from Murphy, the site upstream of the mouth of the Boise River and Brownlee. Total lengths were between 305 and $452 \mathrm{~mm}$ with the largest fish sampled from Brownlee (fig. 4B). Median $\mathrm{Hg}$ concentrations in smallmouth bass were $0.17 \mathrm{mg} / \mathrm{kg}$ from Murphy and $0.32 \mathrm{mg} / \mathrm{kg}$ from Brownlee (fig. 3). Brownlee smallmouth bass exceeded the Idaho water-quality criterion, RPTE threshold level, and the IFCAP action level (table 5, fig. 3).

Channel catfish were collected from the Boise mouth, Murphy, and Nyssa sites. Individual fish lengths were between 510 and $708 \mathrm{~mm}$ with the largest individual fish sampled from Murphy. There was no discernible relation between fish length and $\mathrm{Hg}$ concentrations in channel catfish (fig. 4C). Median $\mathrm{Hg}$ concentrations in channel catfish tissue were $0.28 \mathrm{mg} / \mathrm{kg}$ from Boise mouth, $0.18 \mathrm{mg} / \mathrm{kg}$ from Murphy, and $0.14 \mathrm{mg} / \mathrm{kg}$ from Nyssa (table 5, fig. 3). Boise mouth channel catfish exceeded the

Idaho water-quality criterion, RPTE threshold level, and the IFCAP action level (table 5, fig. 3). Median $\mathrm{Hg}$ concentrations were similar between the channel catfish $(0.18 \mathrm{mg} / \mathrm{kg})$ and smallmouth bass from Murphy $(0.17 \mathrm{mg} / \mathrm{kg})$.

\section{Selenium in Fish Tissue}

The concentration of Se in composite fish-tissue samples from the Boise and Snake Rivers and Brownlee Reservoir collected in October 2013 are given in table 6. Percent water, percent solids, and wet weight concentrations are given to better compare the results to $\mathrm{Hg}$ wet-weight concentrations. Concentrations of Se ranged from 0.07 to $0.49 \mathrm{mg} / \mathrm{kg}$ wet weight; concentrations were lowest for mountain whitefish and highest for smallmouth bass. 


\section{Summary}

Water samples and sport fish of edible size were collected for mercury $(\mathrm{Hg})$ analysis from six sites in the Boise and Snake Rivers and Brownlee Reservoir to meet a portion of the City of Boise's National Pollution Discharge and Elimination System Hg monitoring requirements. One water sample was collected from each of the six sites. Ten mountain whitefish were collected from each of the Boise River sites at Eckert and Middleton. Ten smallmouth bass were collected from Murphy and Brownlee. Ten channel catfish were collected from Boise mouth, and from Murphy and Nyssa, upstream and downstream of the confluence of the Boise and Snake Rivers. Two different species, smallmouth bass and channel catfish, were collected from Murphy to compare $\mathrm{Hg}$ concentrations between species.

$\mathrm{Hg}$ concentrations in water ranged from 0.73 to $1.21 \mathrm{ng} / \mathrm{L}$ for the five river sites. $\mathrm{Hg}$ concentration was highest $(8.78 \mathrm{ng} / \mathrm{L})$ in a water sample from the Brownlee Reservoir at Burnt River site (Brownlee). All samples were less than EPA aquatic life criteria (12 ng/L).

Median fish-tissue $\mathrm{Hg}$ concentrations ranged between $0.17 \mathrm{mg} / \mathrm{kg}$ in mountain whitefish from Boise River near Middleton, Idaho site and $0.32 \mathrm{mg} / \mathrm{kg}$ in smallmouth bass from Brownlee. $\mathrm{Hg}$ concentrations in channel catfish from the Boise River at mouth near Parma, Idaho and smallmouth bass from Brownlee exceeded the Idaho water-quality criterion $(0.30 \mathrm{mg} / \mathrm{kg})$, reasonable potential to exceed threshold level $(>0.24 \mathrm{mg} / \mathrm{kg})$, and the Idaho Fish Consumption Advisory Program action level (0.22 $\mathrm{mg} / \mathrm{kg}$ ).

Concentrations of Se in fish tissue collected from the Boise and Snake Rivers and Brownlee Reservoir were between 0.07 and $0.49 \mathrm{mg} / \mathrm{kg}$ wet weight. Se concentrations were lowest in mountain whitefish and highest in smallmouth bass. Se composite samples collected in this study may provide information for comparing Se concentrations between species and for future use in fish consumption advisories. 


\section{References Cited}

Bloom, N.S., 1992, On the chemical form of mercury in edible fish and marine invertebrate tissue: Canadian Journal of Fisheries and Aquatic Sciences, v. 49, no. 5, p. 1010-1017, accessed March 10, 2014, at http://dx.doi.org/10.1139/f92-113.

Clark, G.M., and Maret, T.R., 1998, Organochlorine compounds and trace elements in fish tissue and bed sediments in the Lower Snake River Basin, Idaho and Oregon: U.S. Geological Survey WaterResources Investigations Report 98-4103, 35 p., http://id.water.usgs.gov/PDF/wri984103/index.html. Essig, D.A., 2010, Arsenic, mercury, and selenium in fish tissue and water from Idaho's major riversA statewide assessment: Boise, Idaho, Idaho Department of Environmental Quality, accessed March 10, 2014, at http://www.deq.idaho.gov/water-quality/surface-water/mercury.aspx.

Essig, D.A., and Kosterman, M.A., 2008, Arsenic, mercury, and selenium in fish tissue from Idaho lakes and reservoirs-A statewide assessment: Boise, Idaho, Idaho Department of Environmental Quality, $80 \mathrm{p}$.

Fitzgerald, W.F., and Lamborg, C.H., 2007, Geochemistry of mercury in the environment: Treatise on Geochemistry, Elsevier, p. 1-47, http://www.sciencedirect.com/science/referenceworks/9780080437514.

Garbarino, J.R., Kanagy, L.K., and Cree, M.E., 2006, Determination of elements in natural-water, biota, sediment, and soil samples using collision/reaction cell inductively coupled plasma-Mass Spectrometry: U.S. Geological Survey Techniques and Methods, book 5, chap. B1, 88 p., http://pubs.usgs.gov/tm/2006/tm5b1/.

Hammerschmidt, C.R., Wiener, J.G., Frazier, B.E., and Rada, R.G., 1999, Methylmercury content of eggs in yellow perch related to maternal exposure in four Wisconsin lakes: Environmental Science and Technology, v. 33, no. 7, p. 999-1,003.

Harris, H.H., Pickering, I.J., and George, G.N., 2003, The chemical form of mercury in fish: Science, v. 301, no. 5637, p. 1,203, accessed March 10, 2014, at http://dx.doi.org/10.1126/science.1085941.

Idaho Department of Environmental Quality, 2005, Implementation guidance for the Idaho mercury water quality criteria: Boise, Idaho, Idaho Department of Environmental Quality, 212 p., accessed March 10, 2014, at http://www.deq.state.id.us/water-quality/surface-water/mercury.aspx.

Idaho Department of Environmental Quality, 2014, Idaho EPA Actions on Proposed Standards, accessed May 12, 2014 at http://www.deq.idaho.gov/epa-actions-on-proposed-standards.

International Atomic Energy Agency, 2003, Trace elements and methylmercury in fish tissue: Reference sheet IAEA-407, accessed May 2, 2014, at http://www.iaea.org/nael/refmaterial/iaea407.pdf.

Lewis, M.E., and Brigham, M.E., 2004, Low-level mercury, in Wilde, F.D., Radtke, D.B., Gibs, J., and Iwatsubo, R.T., eds., Chapter A5 processing of water samples-National field manual for the collection of water-quality data: U.S. Geological Survey Techniques of Water-Resources Investigations, book 9, accessed March 10, 2014, at http://pubs.water.usgs.gov/twri9A5/.

MacCoy, D.E., 2006, Fish communities and related environmental conditions of the lower Boise River, southwestern Idaho, 1974-2004: U.S. Geological Survey Scientific Investigations Report 2006-5111, 36 p., http://pubs.usgs.gov/sir/2006/5111/.

Mebane, C.A., and MacCoy, D.E., 2013, Monitoring plan for mercury in fish tissue and water from the Boise River, Snake River, and Brownlee Reservoir, Idaho and Oregon: U.S. Geological Survey OpenFile Report 2013-1068, 24 p., http://pubs.usgs.gov/of/2013/1068/. 
Richter, T.J., and Chandler, J.A., 2003, Water-level impacts to spawning smallmouth bass, crappie spp., and channel catfish, in Richter, T.J., ed., Hells Canyon complex resident fish study, revised 2003: Boise, Idaho, Idaho Power Company, 76 p., accessed March 10, 2014, at http://www.idahopower.com/pdfs/Relicensing/hellscanyon/hellspdfs/techappendices/Aquatic/e31_05_ ch01.pdf.

Riva-Murray, K., Bradley, P.M., Scudder Eikenberry, B.C., Knightes, C.D., Journey, C.A., Brigham, M.E., and Button, D.T., 2012, Optimizing stream water mercury sampling for calculation of fish bioaccumulation factors: Environmental Science and Technology, http://dx.doi.org/10.1021/es303758e.

Scudder, B.C., Chasar, L.C., DeWeese, L.R., Brigham, M.E., Wentz, D.A., and Brumbaugh, W.G., 2008, Procedures for collecting and processing aquatic invertebrates and fish for analysis of mercury as part of the National Water-Quality Assessment Program: U.S. Geological Survey Open-File Report 2008-1208, 34 p., http://pubs.usgs.gov/of/2008/1208/.

U.S. Environmental Protection Agency, 2001, Water quality criterion for the protection of human health-Methylmercury: Washington, D.C., EPA-823-R-01-001, 303 p., accessed March 10, 2014, at http:/www.epa.gov/waterscience/criteria/methylmercury/.

U.S. Environmental Protection Agency, 2007, Mercury in solids and solutions by thermal decomposition, amalgamation, and atomic absorption spectrophotometry: Washington, D.C., EPA Method 7473 (SW-846), accessed March 10, 2014, at www.epa.gov/osw/hazard/testmethods/sw846/pdfs/7473.pdf.

U.S. Environmental Protection Agency, 2010, Guidance for implementing the January 2001 methylmercury water quality criteria: Washington, D.C., EPA-823-R-10-001, 221 p., accessed March 10, 2014, at http://www.epa.gov/waterscience/criteria/methylmercury/.

U.S. Environmental Protection Agency, 2012a, National Pollutant Discharge Elimination System (NPDES) website: accessed March 19, 2014, at http://cfpub.epa.gov/npdes/about.cfm?program_id=0.

U.S. Environmental Protection Agency, 2012b, Authorization to discharge under the National Pollutant Discharge Elimination System-Lander Street Wastewater Treatment Facility, City of Boise: U.S. Environmental Protection Agency, Permit No.: ID-002044-3, 53 p., accessed March 10, 2014, at http://yosemite.epa.gov/r10/water.nsf/NPDES+Permits/Current+ID1319.

U.S. Environmental Protection Agency, 2012c, Authorization to discharge under the National Pollutant Discharge Elimination System -West Boise Wastewater Treatment Facility, City of Boise: U.S. Environmental Protection Agency, Permit No. ID-002044-3, 52 p., accessed March 10, 2014, at http://yosemite.epa.gov/r10/water.nsf/NPDES+Permits/Current+ID1319.

U.S. Environmental Protection Agency, Office of Water, 2002, Method 1631, Revision E-Mercury in water by oxidation, purge and trap, and cold vapor atomic fluorescence spectrometry: Washington, D.C., EPA-821-R-02-019, 46 p., accessed March 10, 2014, at http://water.epa.gov/scitech/methods/cwa/metals/mercury/index.cfm.

U.S. Geological Survey, 2013, USGS Mercury Research Laboratory: Website, accessed April 25, 2014, at http://wi.water.usgs.gov/mercury-lab/index.html.

U.S. Geological Survey, 2014, USGS Water-quality for Idaho: Website, accessed April 25, 2014, at http://waterdata.usgs.gov/id/nwis/qw.

Wilde, F.D., ed., 2006, Collection of water samples: U.S. Geological Survey Techniques of WaterResources Investigations, book 9, chap A4 (v. 2.0), 231 p., accessed March 10, 2014, at http://water.usgs.gov/owq/FieldManual/chapter4/html/Ch4_contents.html. 


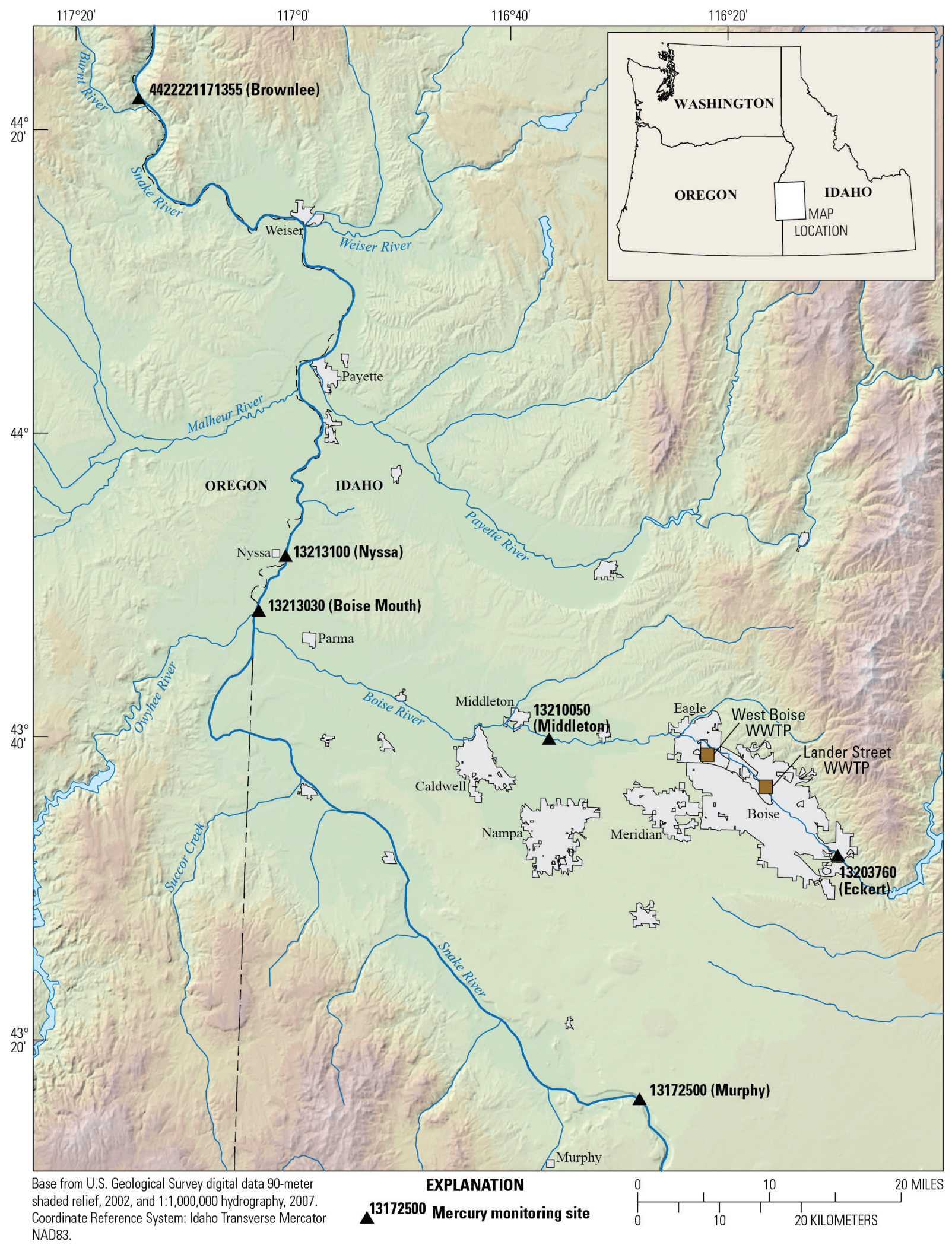

Figure 1. Map showing location of sites where water and fish tissue samples were collected for analysis of total mercury and selenium, Idaho and Oregon, October 2013. 


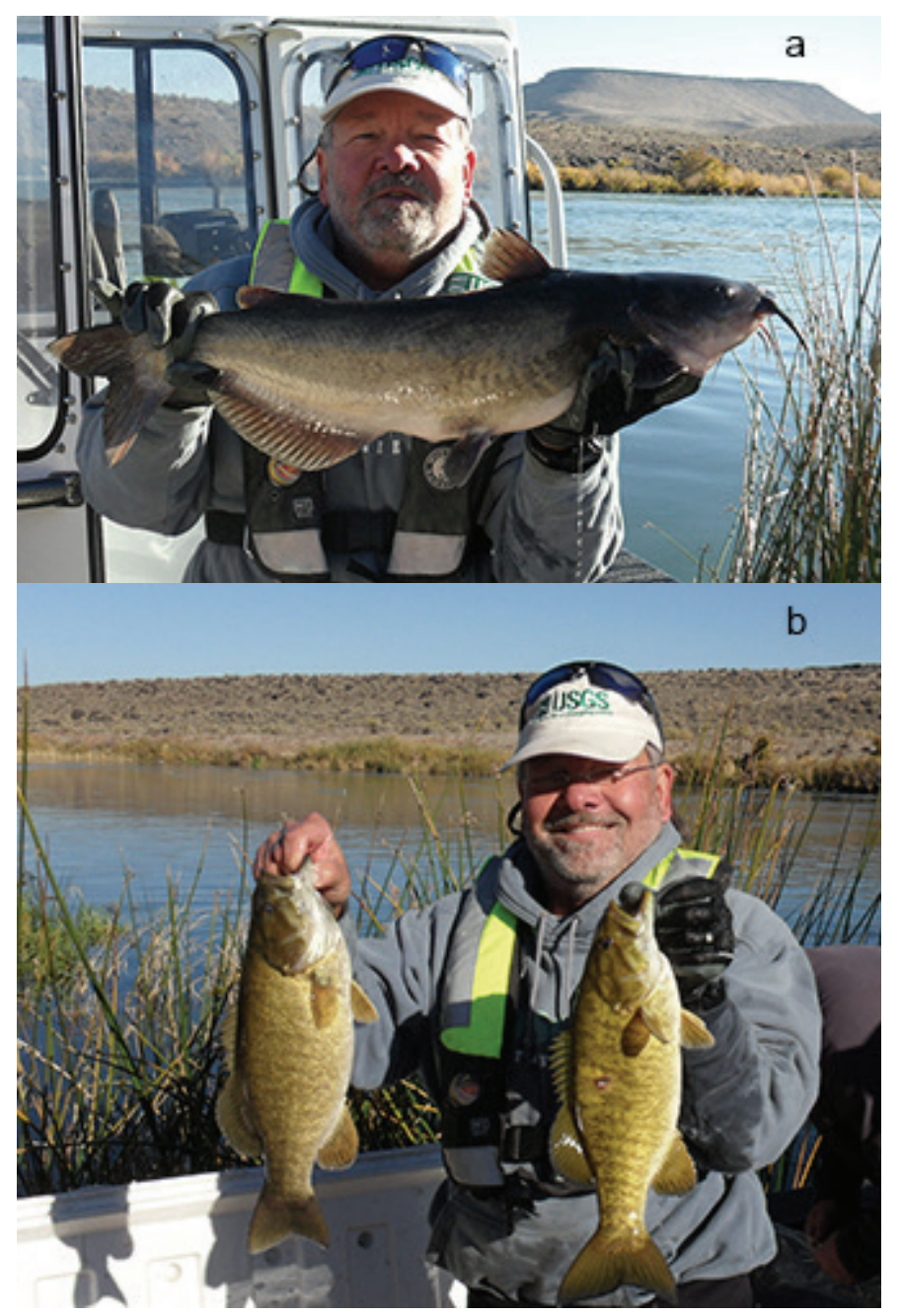

Figure 2. Photographs of channel catfish $(A)$ and smallmouth bass $(B)$ at the Snake River near Murphy sampling site, October 2013. (Photographs taken by Dorene MacCoy) 


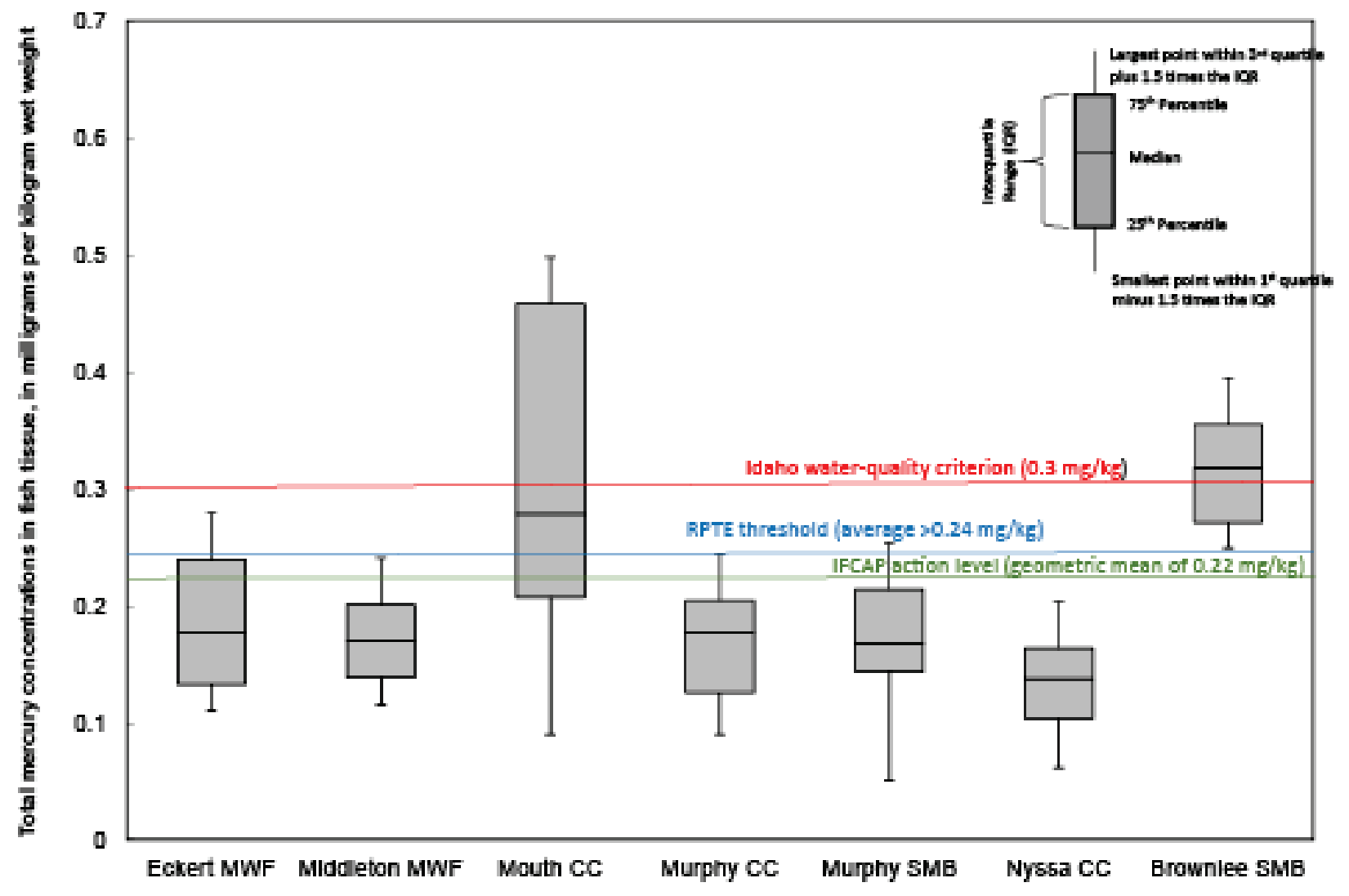

Figure 3. Boxplot showing total mercury concentrations in fish tissue collected from sites in the Boise and Snake Rivers and Brownlee Reservoir, October 2013, Idaho and Oregon. (CC, channel catfish; SMB, smallmouth bass; MWF, mountain whitefish; RPTE threshold, reasonable potential to exceed 80 percent of the Idaho mercury waterquality criterion of 0.30 milligrams per kilogram $(\mathrm{mg} / \mathrm{kg}$ ) wet weight mercury or greater than $0.24 \mathrm{mg} / \mathrm{kg}$ in an average of 10 fish; IFCAP action level, Idaho Fish Consumption Advisory Project recommends consideration of issuing a fish advisory when the geometric mean of mercury in 10 fish exceeds $0.22 \mathrm{mg} / \mathrm{kg}$ wet weight). Site names are shown in table 1. 


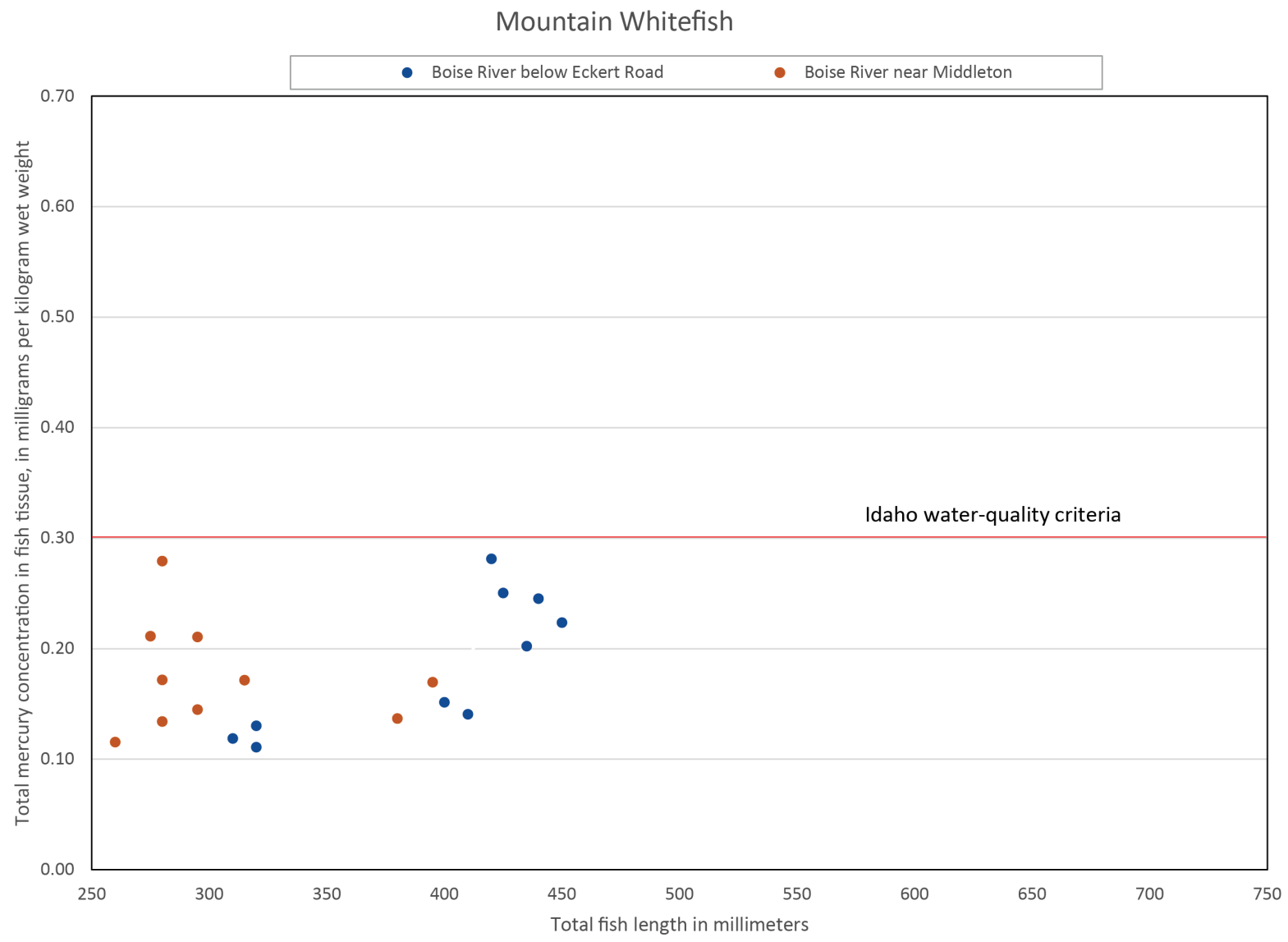

A.

Figure 4. Graphs showing total mercury tissue concentrations and total length of mountain whitefish $(A)$, smallmouth bass $(B)$ and channel catfish $(C)$ in samples from the Boise and Snake Rivers and Brownlee Reservoir, Idaho and Oregon, October 2013. 


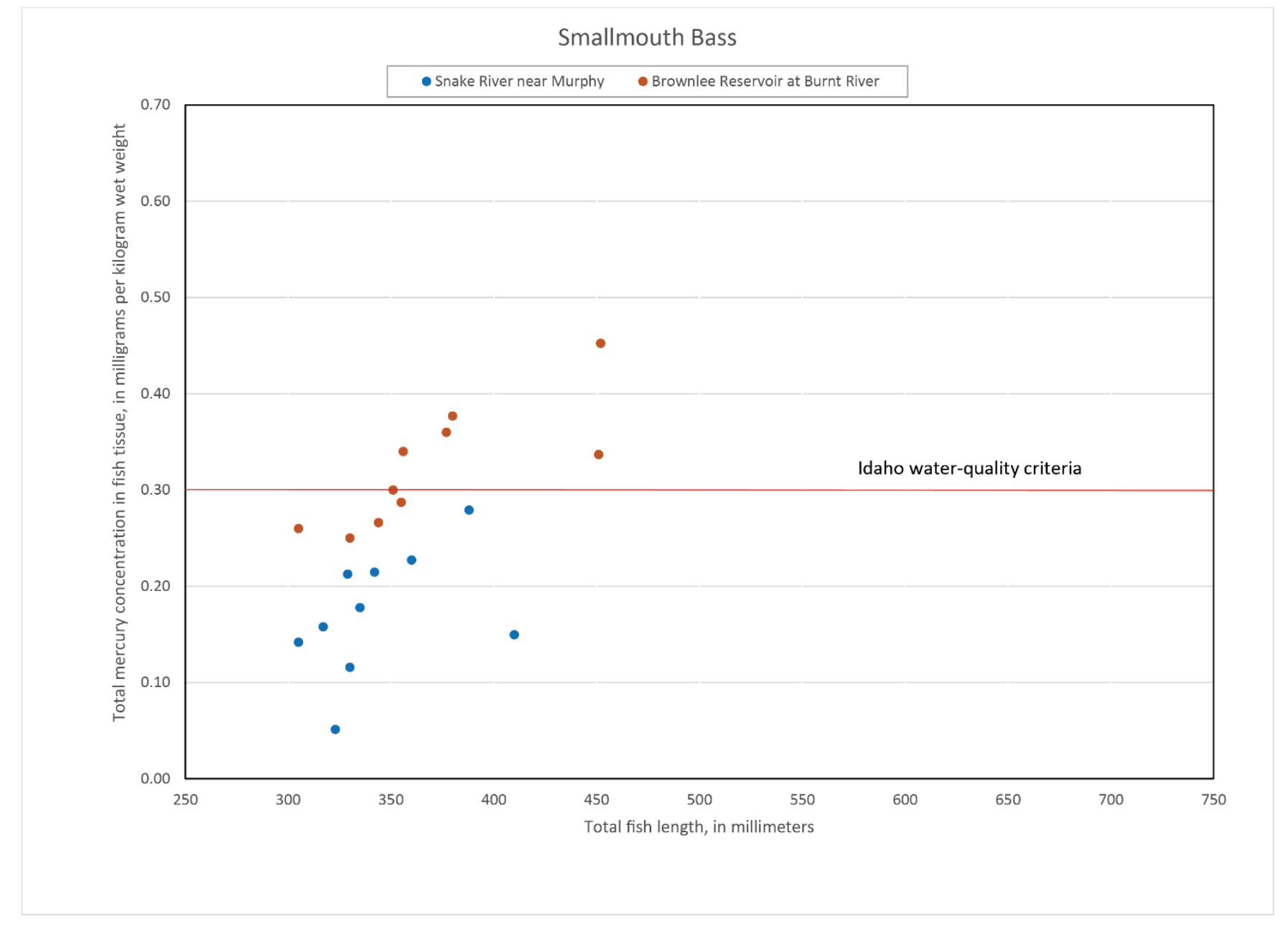

B.

Figure 4. -Continued. 


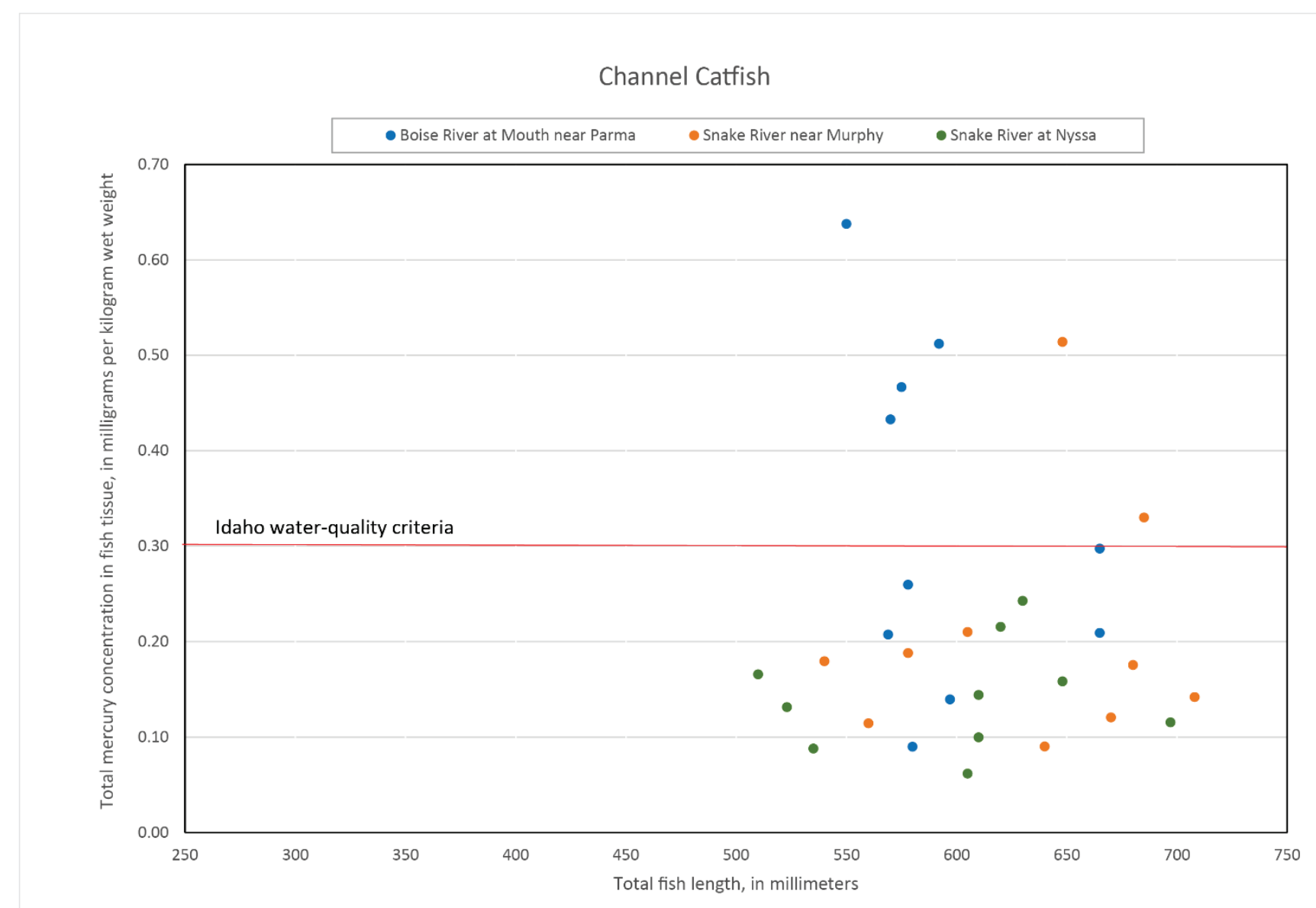

C.

Figure 4. -Continued. 
Table 1. Sites in the Boise and Snake Rivers and Brownlee Reservoir where water and fish samples were collected for mercury analysis, Idaho and Oregon, 2013.

[Site locations are shown in figure 1. NAD83, North American Datum of 1983]

\begin{tabular}{lllll}
\hline $\begin{array}{c}\text { USGS site } \\
\text { identification }\end{array}$ & \multicolumn{1}{c}{ Site name } & $\begin{array}{c}\text { Site short } \\
\text { name }\end{array}$ & $\begin{array}{c}\text { Decimal } \\
\text { latitude } \\
\text { (NAD83) }\end{array}$ & $\begin{array}{c}\text { Decimal longitude } \\
\text { (NAD83) }\end{array}$ \\
\hline 13203760 & Boise River at Eckert Road, near Boise, Idaho & Eckert & 43.56572 & -116.13205 \\
13210050 & Boise River near Middleton, Idaho & Middleton & 43.68488 & -116.57374 \\
13213030 & Boise River at mouth, near Parma, Idaho & Boise Mouth & 43.81516 & -117.02043 \\
13172500 & Snake River near Murphy, Idaho & Murphy & 43.29183 & -116.42094 \\
13213100 & Snake River at Nyssa, Oregon & Nyssa & 43.87611 & -116.9825 \\
4422221171355 & Brownlee Reservoir at Burnt River, Oregon & Brownlee & 44.37266 & -117.23295 \\
\hline
\end{tabular}

Table 2. Targeted fish species in the Boise and Snake Rivers and Brownlee Reservoir, Idaho and Oregon.

[Site locations are shown in figure 1. Species in bold were collected in October 2013 for tissue analysis]

\begin{tabular}{|c|c|c|}
\hline $\begin{array}{c}\begin{array}{c}\text { USGS site } \\
\text { identification }\end{array} \\
\end{array}$ & Site name & Expected species \\
\hline 13203760 & Boise River at Eckert Road, near Boise, Idaho & $\begin{array}{l}\text { Mountain whitefish (Prosopium } \\
\text { williamsoni), brown trout (Salmo trutta), } \\
\text { rainbow trout (Oncorhynchus mykiss) }\end{array}$ \\
\hline 13210050 & Boise River near Middleton, Idaho & $\begin{array}{l}\text { Mountain whitefish, brown trout, } \\
\text { largemouth bass (Micropterus salmoides), } \\
\text { smallmouth bass (Micropterus dolomieui) }\end{array}$ \\
\hline 13213030 & Boise River at mouth, near Parma, Idaho & $\begin{array}{l}\text { Mountain whitefish, largemouth bass, } \\
\text { smallmouth bass, channel catfish (Ictalurus } \\
\text { punctatus) }\end{array}$ \\
\hline 13172500 & Snake River near Murphy, Idaho & $\begin{array}{l}\text { Smallmouth bass, largemouth bass, channel } \\
\text { catfish }\end{array}$ \\
\hline 13213100 & Snake River at Nyssa, Oregon & $\begin{array}{l}\text { Smallmouth bass, mountain whitefish, } \\
\text { largemouth bass, channel catfish }\end{array}$ \\
\hline 4422221171355 & Brownlee Reservoir at Burnt River, Oregon & $\begin{array}{l}\text { Smallmouth bass, crappie spp. (Pomoxis } \\
\text { sp.), largemouth bass, channel catfish }\end{array}$ \\
\hline
\end{tabular}


Table 3. Quality-control sample results for analysis of total mercury in fish from the Boise and Snake Rivers and Brownlee Reservoir, Idaho and Oregon, October 2013.

[Certified reference material from the International Atomic Energy Agency, laboratory identification number beginning with IAEA (2003); a description of IAEA-407 is available at http://www.iaea.org/nael/refmaterial/iaea407.pdf. Triplicate samples from a single fish at a sampling site (laboratory identification samples beginning with MSC) were analyzed separate from the original sample for laboratory method repeatability (precision) and reported as relative standard deviation (RSD), $\mathrm{RSD}=$ Standard deviation of the three replicate concentrations divided by the average of those replicates. ng/g, nanograms per gram]

\begin{tabular}{|c|c|c|c|c|}
\hline \multicolumn{5}{|c|}{ Certified } \\
\hline $\begin{array}{l}\text { Laboratory } \\
\text { identification }\end{array}$ & $\begin{array}{l}\text { Date of } \\
\text { analysis }\end{array}$ & $\begin{array}{l}\text { Mercury, ng/g } \\
\text { dry weight }\end{array}$ & $\begin{array}{l}\text { Laboratory detection } \\
\text { limit, ng/g dry weight }\end{array}$ & $\begin{array}{c}\text { Certified reference } \\
\text { material percent } \\
\text { recovery }\end{array}$ \\
\hline IAEA-407 & $2 / 18 / 2014$ & 213 & 2.99 & 96.02 \\
\hline IAEA-407 & $2 / 18 / 2014$ & 221 & 3.4 & 99.57 \\
\hline IAEA-407 & $2 / 18 / 2014$ & 224 & 3.56 & 100.81 \\
\hline IAEA-407 & $2 / 18 / 2014$ & 240 & 4.22 & 108.12 \\
\hline IAEA-407 & $2 / 18 / 2014$ & 246 & 3.48 & 110.74 \\
\hline IAEA-407 & $2 / 18 / 2014$ & 238 & 2.46 & 107.21 \\
\hline IAEA-407 & $2 / 19 / 2014$ & 236 & 5.31 & 106.35 \\
\hline IAEA-407 & $2 / 19 / 2014$ & 248 & 6.1 & 111.77 \\
\hline IAEA-407 & $2 / 19 / 2014$ & 248 & 4.63 & 111.78 \\
\hline IAEA-407 & $2 / 19 / 2014$ & 247 & 6.02 & 111.23 \\
\hline IAEA-407 & $2 / 19 / 2014$ & 249 & 6.45 & 112.08 \\
\hline IAEA-407 & $2 / 19 / 2014$ & 248 & 7.3 & 111.72 \\
\hline IAEA-407 & $2 / 19 / 2014$ & 244 & 6.57 & 109.92 \\
\hline IAEA-407 & $2 / 19 / 2014$ & 250 & 6.39 & 112.54 \\
\hline IAEA-407 & $2 / 19 / 2014$ & 248 & 5.95 & 111.53 \\
\hline IAEA-407 & $2 / 20 / 2014$ & 237 & 10.53 & 106.9 \\
\hline IAEA-407 & $2 / 20 / 2014$ & 247 & 7.72 & 111.45 \\
\hline IAEA-407 & $2 / 20 / 2014$ & 247 & 10.48 & 111.14 \\
\hline IAEA-407 & $2 / 20 / 2014$ & 254 & 7.02 & 114.26 \\
\hline IAEA-407 & $2 / 20 / 2014$ & 255 & 11.29 & 114.86 \\
\hline IAEA-407 & $2 / 21 / 2014$ & 249 & 5.68 & 112.05 \\
\hline IAEA-407 & $2 / 21 / 2014$ & 242 & 3.91 & 109.13 \\
\hline IAEA-407 & $2 / 21 / 2014$ & 240 & 4.51 & 108.26 \\
\hline IAEA-407 & $2 / 21 / 2014$ & 245 & 4.29 & 110.35 \\
\hline IAEA-407 & $2 / 24 / 2014$ & 238 & 4.73 & 107.38 \\
\hline IAEA-407 & $2 / 24 / 2014$ & 242 & 4.59 & 108.93 \\
\hline IAEA-407 & $2 / 24 / 2014$ & 251 & 4.99 & 113.2 \\
\hline
\end{tabular}




\begin{tabular}{|c|c|c|c|c|}
\hline \multicolumn{5}{|c|}{ Triplicate } \\
\hline $\begin{array}{l}\text { Laboratory } \\
\text { identification }\end{array}$ & $\begin{array}{l}\text { Date of } \\
\text { analysis }\end{array}$ & $\begin{array}{l}\text { Mercury, ng/g } \\
\text { dry weight }\end{array}$ & $\begin{array}{l}\text { Laboratory detection } \\
\text { limit, ng/g dry weight }\end{array}$ & $\begin{array}{l}\text { Triplicate relative } \\
\text { standard deviation } \\
\text { (percent) }\end{array}$ \\
\hline MSC568T & $2 / 18 / 2014$ & 957 & 4.1 & 1.1 \\
\hline MSC568T & $2 / 18 / 2014$ & 975 & 3.88 & \\
\hline MSC568T & $2 / 18 / 2014$ & 976 & 4.1 & \\
\hline MSC718T & $2 / 18 / 2014$ & 929 & 4.42 & 1.43 \\
\hline MSC718T & $2 / 18 / 2014$ & 956 & 4.04 & \\
\hline MSC718T & $2 / 18 / 2014$ & 948 & 3.83 & \\
\hline MSC299T & $2 / 19 / 2014$ & 714 & 10.1 & 1.2 \\
\hline MSC299T & $2 / 19 / 2014$ & 697 & 8.92 & \\
\hline MSC299T & $2 / 19 / 2014$ & 704 & 6.69 & \\
\hline MSC565T & $2 / 19 / 2014$ & 1,215 & 12.14 & 0.91 \\
\hline MSC565T & $2 / 19 / 2014$ & 1,227 & 12.9 & \\
\hline MSC565T & $2 / 19 / 2014$ & 1,237 & 11.38 & \\
\hline MSC887T & $2 / 19 / 2014$ & 328 & 8.35 & 4.39 \\
\hline MSC $887 \mathrm{~T}$ & $2 / 19 / 2014$ & 351 & 7.34 & \\
\hline MSC887T & $2 / 19 / 2014$ & 357 & 13.38 & \\
\hline MSC891T & $2 / 20 / 2014$ & 3,035 & 13.03 & 3.27 \\
\hline MSC891T & $2 / 20 / 2014$ & 3,173 & 15.12 & \\
\hline MSC891T & $2 / 20 / 2014$ & 3,237 & 15.57 & \\
\hline MSC726T & $2 / 21 / 2014$ & 626 & 5.71 & 2.4 \\
\hline MSC726T & $2 / 21 / 2014$ & 656 & 5.15 & \\
\hline MSC726T & $2 / 21 / 2014$ & 648 & 5.78 & \\
\hline MSC730T & $2 / 21 / 2014$ & 982 & 7.45 & 2.08 \\
\hline MSC730T & $2 / 21 / 2014$ & 1,020 & 7.73 & \\
\hline MSC730T & $2 / 21 / 2014$ & 988 & 6.37 & \\
\hline
\end{tabular}


Table 4. Total mercury concentrations in water from the Boise and Snake Rivers and Brownlee Reservoir, and associated field blanks and laboratory matrix spike recovery for samples collected in October and November 2013.

[Site locations are shown in figure 1. Samples collected by City of Boise personnel and analyzed by Boise City Public Works Water Quality Laboratory, Boise, Idaho. <, less than]

\begin{tabular}{llcrrr}
\hline $\begin{array}{c}\text { USGS site } \\
\text { identification }\end{array}$ & \multicolumn{1}{c}{ Site name } & $\begin{array}{c}\text { Sample } \\
\text { date }\end{array}$ & $\begin{array}{c}\text { Sample } \\
\text { time }\end{array}$ & $\begin{array}{c}\text { Total mercury } \\
\text { concentration } \\
\text { (ng/L) }\end{array}$ & $\begin{array}{c}\text { Field blank } \\
\text { concentration } \\
\text { (ng/L) }\end{array}$ \\
\hline 13203760 & Boise River at Eckert Road, near Boise, Idaho & $11 / 1 / 2013$ & 0937 & 0.73 & 0.22 \\
13210050 & Boise River near Middleton, Idaho & $11 / 1 / 2013$ & 1057 & 0.89 & $<0.20$ \\
13213030 & Boise River at mouth, near Parma, Idaho & $11 / 1 / 2013$ & 1221 & 1.21 & 0.70 \\
13172500 & Snake River near Murphy, Idaho & $10 / 28 / 2013$ & 1515 & 0.93 & $<0.20$ \\
13213100 & Snake River at Nyssa, Oregon & $10 / 28 / 2013$ & 1323 & 1.20 & $<0.20$ \\
4422221171355 & Brownlee Reservoir at Burnt River, Oregon & $10 / 28 / 2013$ & 1138 & 8.78 & $<0.20$ \\
\hline
\end{tabular}

Boise City Public Works Water Quality Laboratory matrix spike recovery

\begin{tabular}{cccc}
\hline $\begin{array}{c}\text { Lab sample } \\
\text { identification }\end{array}$ & Date of analysis & $\begin{array}{c}\text { Total mercury spike } \\
\text { concentration }(\mu \mathrm{g} / \mathrm{L})\end{array}$ & $\begin{array}{c}\text { Percent } \\
\text { recovery }\end{array}$ \\
\hline AP07402 & $11 / 12 / 2013$ & 0.19 & 100.5 \\
AP07406 & $11 / 12 / 2013$ & 0.19 & 96.5 \\
\hline
\end{tabular}

${ }^{a}$ Environmental Protection Agency total mercury chronic aquatic life criteria for Idaho is 12 ng/L (Idaho Department of Environmental Quality, variously dated). 
Table 5. Individual sport fish tissue total mercury concentrations, fish size data, and statistical site summaries in samples collected from the Boise and Snake Rivers and Brownlee Reservoir, Idaho and Oregon, October 2013.

[Site locations are shown in figure 1. g, gram; mm, millimeter; $\mathrm{mg} / \mathrm{kg}$, milligram per kilogram]

\begin{tabular}{|c|c|c|c|c|c|c|c|c|c|c|c|}
\hline Site name & $\begin{array}{c}\text { Sample } \\
\text { date }\end{array}$ & Time & $\begin{array}{c}\text { Total } \\
\text { length } \\
(\mathrm{mm})\end{array}$ & $\begin{array}{l}\text { Weight } \\
\text { (g) }\end{array}$ & $\begin{array}{c}\text { Mercury, } \\
\text { dry } \\
\text { weight } \\
(\mathrm{mg} / \mathrm{kg})\end{array}$ & $\begin{array}{c}\text { Percent } \\
\text { water }\end{array}$ & $\begin{array}{l}\text { Percent } \\
\text { Solids }\end{array}$ & $\begin{array}{l}\text { Mercury, } \\
\text { wet weight } \\
(\mathrm{mg} / \mathrm{kg})\end{array}$ & $\begin{array}{l}\text { Mercury, wet } \\
\text { weight } \\
\text { geometric } \\
\text { mean per site } \\
(\mathrm{mg} / \mathrm{kg})\end{array}$ & $\begin{array}{c}\text { Mercury, } \\
\text { wet weight } \\
\text { median per } \\
\text { site }(\mathrm{mg} / \mathrm{kg} \text { ) }\end{array}$ & $\begin{array}{c}\text { Mercury, } \\
\text { wet weight } \\
\text { average per } \\
\text { site }(\mathrm{mg} / \mathrm{kg} \text { ) }\end{array}$ \\
\hline \multicolumn{12}{|c|}{ Mountain whitefish } \\
\hline Boise River at Eckert & $10 / 29 / 2013$ & 1001 & 440 & 959 & 0.975 & 74.84 & 25.16 & 0.25 & 0.18 & 0.18 & 0.19 \\
\hline \multirow[t]{9}{*}{ Road, near Boise, Idaho } & & 1002 & 420 & 626 & 1.19 & 76.36 & 23.64 & 0.28 & & & \\
\hline & & 1003 & 450 & 850 & 0.94 & 76.21 & 23.79 & 0.22 & & & \\
\hline & & 1004 & 400 & 702 & 0.507 & 70.11 & 29.89 & 0.15 & & & \\
\hline & & 1005 & 425 & 699 & 0.851 & 70.57 & 29.43 & 0.25 & & & \\
\hline & & 1006 & 435 & 866 & 0.626 & 67.68 & 32.32 & 0.20 & & & \\
\hline & & 1007 & 410 & 636 & 0.58 & 75.74 & 24.26 & 0.14 & & & \\
\hline & & 1008 & 320 & 360 & 0.436 & 74.56 & 25.44 & 0.11 & & & \\
\hline & & 1009 & 310 & 330 & 0.418 & 71.58 & 28.42 & 0.12 & & & \\
\hline & & 1010 & 320 & 315 & 0.498 & 73.84 & 26.16 & 0.13 & & & \\
\hline Boise River near & $10 / 21 / 2013$ & 1201 & 380 & 491 & 0.527 & 74.03 & 25.97 & 0.14 & 0.17 & 0.17 & 0.17 \\
\hline \multirow[t]{9}{*}{ Middleton, Idaho } & & 1202 & 280 & 182 & 1.08 & 74.14 & 25.86 & 0.28 & & & \\
\hline & & 1203 & 395 & 506 & 0.652 & 73.97 & 26.03 & 0.17 & & & \\
\hline & & 1204 & 295 & 217 & 0.948 & 77.78 & 22.22 & 0.21 & & & \\
\hline & & 1205 & 315 & 321 & 0.708 & 75.77 & 24.23 & 0.17 & & & \\
\hline & & 1206 & 280 & 207 & 0.783 & 78.06 & 21.94 & 0.17 & & & \\
\hline & & 1207 & 280 & 186 & 0.534 & 74.88 & 25.12 & 0.13 & & & \\
\hline & & 1208 & 295 & 211 & 0.625 & 76.81 & 23.19 & 0.14 & & & \\
\hline & & 1209 & 275 & 190 & 0.906 & 76.67 & 23.33 & 0.21 & & & \\
\hline & & 1210 & 260 & 149 & 0.433 & 73.32 & 26.68 & 0.12 & & & \\
\hline
\end{tabular}




\begin{tabular}{|c|c|c|c|c|c|c|c|c|c|c|c|}
\hline Site name & $\begin{array}{c}\text { Sample } \\
\text { date }\end{array}$ & Time & $\begin{array}{c}\text { Total } \\
\text { length } \\
(\mathrm{mm})\end{array}$ & $\begin{array}{l}\text { Weight } \\
\text { (g) }\end{array}$ & $\begin{array}{c}\text { Mercury, } \\
\text { dry } \\
\text { weight } \\
\text { (mg/kg) }\end{array}$ & $\begin{array}{l}\text { Percent } \\
\text { water }\end{array}$ & $\begin{array}{l}\text { Percent } \\
\text { Solids }\end{array}$ & $\begin{array}{l}\text { Mercury, } \\
\text { wet weight } \\
(\mathrm{mg} / \mathrm{kg})\end{array}$ & $\begin{array}{l}\text { Mercury, wet } \\
\text { weight } \\
\text { geometric } \\
\text { mean per site } \\
(\mathrm{mg} / \mathrm{kg})\end{array}$ & $\begin{array}{c}\text { Mercury, } \\
\text { wet weight } \\
\text { median per } \\
\text { site }(\mathrm{mg} / \mathrm{kg} \text { ) }\end{array}$ & $\begin{array}{c}\text { Mercury, } \\
\text { wet weight } \\
\text { average per } \\
\text { site }(\mathrm{mg} / \mathrm{kg})\end{array}$ \\
\hline \multicolumn{12}{|c|}{ Channel catfish } \\
\hline \multirow{10}{*}{$\begin{array}{l}\text { Boise River at mouth, } \\
\text { near Parma, Idaho }\end{array}$} & $10 / 30 / 2013$ & 1501 & 665 & 3,485 & 1.58 & 81.18 & 18.82 & 0.30 & 0.28 & 0.28 & 0.33 \\
\hline & & 1502 & 580 & 2,086 & 0.35 & 74.29 & 25.71 & 0.09 & & & \\
\hline & & 1503 & 570 & 1,595 & 2.23 & 80.59 & 19.41 & 0.43 & & & \\
\hline & & 1504 & 550 & 1,211 & 3.17 & 79.88 & 20.12 & 0.64 & & & \\
\hline & & 1505 & 665 & 3,080 & 1.08 & 80.65 & 19.35 & 0.21 & & & \\
\hline & & 1506 & 592 & 2,245 & 2.33 & 78.02 & 21.98 & 0.51 & & & \\
\hline & & 1507 & 578 & 2,017 & 1.25 & 79.22 & 20.78 & 0.26 & & & \\
\hline & & 1508 & 569 & 2,007 & 1.02 & 79.68 & 20.32 & 0.21 & & & \\
\hline & & 1509 & 575 & 1,785 & 2.29 & 79.62 & 20.38 & 0.47 & & & \\
\hline & & 1510 & 597 & 2,326 & 0.644 & 78.35 & 21.65 & 0.14 & & & \\
\hline Snake River near & $10 / 22 / 2013$ & 1201 & 540 & 1,747 & 0.889 & 79.83 & 20.17 & 0.18 & 0.18 & 0.18 & 0.21 \\
\hline \multirow[t]{9}{*}{ Murphy, Idaho } & & 1202 & 578 & 1,841 & 0.898 & 79.06 & 20.94 & 0.19 & & & \\
\hline & & 1203 & 670 & 2,663 & 0.568 & 78.79 & 21.21 & 0.12 & & & \\
\hline & & 1204 & 648 & 2,526 & 2.7 & 80.96 & 19.04 & 0.51 & & & \\
\hline & & 1205 & 708 & 3,880 & 0.648 & 78.09 & 21.91 & 0.14 & & & \\
\hline & & 1206 & 560 & 1,717 & 0.536 & 78.64 & 21.36 & 0.11 & & & \\
\hline & & 1207 & 685 & 3,526 & 1.65 & 79.83 & 20.17 & 0.33 & & & \\
\hline & & 1208 & 640 & 2,715 & 0.446 & 79.02 & 20.98 & 0.09 & & & \\
\hline & & 1209 & 605 & 2,496 & 0.988 & 79.13 & 20.87 & 0.21 & & & \\
\hline & & 1210 & 680 & 3,017 & 0.853 & 79.42 & 20.58 & 0.18 & & & \\
\hline \multicolumn{12}{|c|}{ Smallmouth bass } \\
\hline Snake River near & $10 / 22 / 2013$ & 1001 & 330 & 557 & 0.517 & 77.63 & 22.37 & 0.12 & 0.16 & 0.17 & 0.17 \\
\hline \multirow[t]{9}{*}{ Murphy, Idaho } & & 1002 & 388 & 906 & 1.28 & 78.19 & 21.81 & 0.28 & & & \\
\hline & & 1003 & 305 & 442 & 0.64 & 77.86 & 22.14 & 0.14 & & & \\
\hline & & 1004 & 410 & 1,108 & 0.659 & 77.3 & 22.7 & 0.15 & & & \\
\hline & & 1005 & 342 & 661 & 0.918 & 76.63 & 23.37 & 0.21 & & & \\
\hline & & 1006 & 323 & 441 & 0.219 & 76.69 & 23.31 & 0.05 & & & \\
\hline & & 1007 & 360 & 689 & 1.03 & 77.94 & 22.06 & 0.23 & & & \\
\hline & & 1008 & 329 & 596 & 0.953 & 77.71 & 22.29 & 0.21 & & & \\
\hline & & 1009 & 335 & 535 & 0.788 & 77.45 & 22.55 & 0.18 & & & \\
\hline & & 1010 & 317 & 457 & 0.696 & 77.34 & 22.66 & 0.16 & & & \\
\hline
\end{tabular}




\begin{tabular}{|c|c|c|c|c|c|c|c|c|c|c|c|}
\hline Site name & $\begin{array}{c}\text { Sample } \\
\text { date }\end{array}$ & Time & $\begin{array}{c}\text { Total } \\
\text { length } \\
(\mathrm{mm})\end{array}$ & $\begin{array}{l}\text { Weight } \\
\text { (g) }\end{array}$ & $\begin{array}{c}\text { Mercury, } \\
\text { dry } \\
\text { weight } \\
(\mathrm{mg} / \mathrm{kg})\end{array}$ & $\begin{array}{l}\text { Percent } \\
\text { water }\end{array}$ & $\begin{array}{l}\text { Percent } \\
\text { Solids }\end{array}$ & $\begin{array}{c}\text { Mercury, } \\
\text { wet weight } \\
(\mathrm{mg} / \mathrm{kg})\end{array}$ & $\begin{array}{l}\text { Mercury, wet } \\
\text { weight } \\
\text { geometric } \\
\text { mean per site } \\
\text { (mg/kg) }\end{array}$ & $\begin{array}{c}\text { Mercury, } \\
\text { wet weight } \\
\text { median per } \\
\text { site }(\mathrm{mg} / \mathrm{kg} \text { ) }\end{array}$ & $\begin{array}{c}\text { Mercury, } \\
\text { wet weight } \\
\text { average per } \\
\text { site }(\mathrm{mg} / \mathrm{kg})\end{array}$ \\
\hline \multicolumn{12}{|c|}{ Channel catfish } \\
\hline Snake River at & $10 / 22 / 2013$ & 1331 & 535 & 1,409 & 0.33 & 73.37 & 26.63 & 0.09 & 0.13 & 0.14 & 0.14 \\
\hline \multirow[t]{9}{*}{ Nyssa, Oregon } & & 1332 & 523 & 1,299 & 0.528 & 75.12 & 24.88 & 0.13 & & & \\
\hline & & 1333 & 510 & 1,202 & 0.704 & 76.47 & 23.53 & 0.17 & & & \\
\hline & & 1334 & 610 & 2,187 & 0.822 & 82.47 & 17.53 & 0.14 & & & \\
\hline & & 1335 & 697 & 2,122 & 0.524 & 77.98 & 22.02 & 0.12 & & & \\
\hline & & 1336 & 605 & 2,228 & 0.247 & 75.04 & 24.96 & 0.06 & & & \\
\hline & & 1337 & 620 & 2,159 & 1.27 & 83.04 & 16.96 & 0.22 & & & \\
\hline & & 1338 & 610 & 2,368 & 0.368 & 72.92 & 27.08 & 0.10 & & & \\
\hline & & 1339 & 648 & 2,399 & 0.821 & 80.72 & 19.28 & 0.16 & & & \\
\hline & & 1340 & 630 & 2,404 & 1.23 & 80.27 & 19.73 & 0.24 & & & \\
\hline \multicolumn{12}{|c|}{ Smallmouth bass } \\
\hline \multirow{10}{*}{$\begin{array}{l}\text { Brownlee Reservoir } \\
\text { at Burnt River, Oregon }\end{array}$} & $10 / 23 / 2013$ & 1401 & 452 & 1,306 & 2.05 & 77.93 & 22.07 & 0.45 & 0.32 & 0.32 & 0.32 \\
\hline & & 1402 & 355 & 647 & 1.28 & 77.57 & 22.43 & 0.29 & & & \\
\hline & & 1403 & 451 & 1,378 & 1.52 & 77.85 & 22.15 & 0.34 & & & \\
\hline & & 1404 & 344 & 620 & 1.17 & 77.26 & 22.74 & 0.27 & & & \\
\hline & & 1405 & 380 & 880 & 1.75 & 78.47 & 21.53 & 0.38 & & & \\
\hline & & 1406 & 330 & 456 & 1.13 & 78.18 & 21.82 & 0.25 & & & \\
\hline & & 1407 & 305 & 424 & 1.18 & 77.81 & 22.19 & 0.26 & & & \\
\hline & & 1408 & 377 & 789 & 1.64 & 78.19 & 21.81 & 0.36 & & & \\
\hline & & 1409 & 351 & 737 & 1.3 & 76.85 & 23.15 & 0.30 & & & \\
\hline & & 1410 & 356 & 673 & 1.52 & 77.74 & 22.26 & 0.34 & & & \\
\hline
\end{tabular}


Table 6. Selenium concentrations in individual sport fish tissue collected from the Boise and Snake Rivers and Brownlee Reservoir, Idaho and Oregon, October 2013.

[Site locations are shown in figure $1 . \mathrm{mg} / \mathrm{kg}$, milligram per kilogram; dry wt, dry weight; wet wt, weight wet]

\begin{tabular}{|c|c|c|c|c|c|c|c|c|}
\hline Site name & $\begin{array}{c}\text { USGS site } \\
\text { Identification }\end{array}$ & $\begin{array}{c}\text { Sample } \\
\text { date }\end{array}$ & Species & $\begin{array}{l}\text { Number in } \\
\text { composite }\end{array}$ & $\begin{array}{l}\text { Selenium } \\
\text { (mg/kg, } \\
\text { dry wt) }\end{array}$ & $\begin{array}{l}\text { Percent } \\
\text { water }\end{array}$ & $\begin{array}{l}\text { Percent } \\
\text { solids }\end{array}$ & $\begin{array}{c}\text { Selenium } \\
\text { (mg/kg, wet wt) }\end{array}$ \\
\hline $\begin{array}{l}\text { Boise River at Eckert Road, } \\
\text { near Boise, Idaho }\end{array}$ & 13203760 & $10 / 29 / 2013$ & Mountain whitefish & 10 & 0.30 & 75.43 & 24.57 & 0.07 \\
\hline $\begin{array}{l}\text { Boise River near } \\
\text { Middleton, Idaho }\end{array}$ & 13210050 & $10 / 21 / 2013$ & Mountain whitefish & 10 & 0.77 & 78.82 & 21.18 & 0.16 \\
\hline $\begin{array}{l}\text { Boise River at mouth, near } \\
\text { Parma, Idaho }\end{array}$ & 13213030 & $10 / 30 / 2013$ & Channel catfish & 10 & 0.72 & 80.57 & 19.43 & 0.14 \\
\hline $\begin{array}{l}\text { Snake River near Murphy, } \\
\text { Idaho }\end{array}$ & 13172500 & $10 / 22 / 2013$ & Channel catfish & 10 & 0.67 & 78.36 & 21.64 & 0.14 \\
\hline $\begin{array}{l}\text { Snake River near Murphy, } \\
\text { Idaho }\end{array}$ & 13172500 & $10 / 22 / 2013$ & Smallmouth bass & 10 & 2.13 & 77.07 & 22.93 & 0.49 \\
\hline $\begin{array}{l}\text { Snake River at Nyssa, } \\
\text { Oregon }\end{array}$ & 13213100 & $10 / 22 / 2013$ & Channel catfish & 10 & 0.88 & 79.79 & 20.21 & 0.18 \\
\hline $\begin{array}{l}\text { Brownlee Reservoir at } \\
\text { Burnt River, Oregon }\end{array}$ & 4422221171355 & $10 / 23 / 2013$ & Smallmouth bass & 10 & 1.48 & 78.39 & 21.61 & 0.32 \\
\hline
\end{tabular}


This page left intentionally blank 
Publishing support provided by the U.S. Geological Survey Publishing Network, Tacoma Publishing Service Center

For additional information contact:

Director, Idaho Water Science Center

U.S. Geological Survey

230 Collins Road

Boise, Idaho 83702

http://id.water.usgs.gov 


\section{है}

3

กั้

I

$\frac{1}{2}$

$\Xi$

$\sum_{3}$

$\stackrel{2}{2}$

3

亲

言

皮

क्ष

車.

궁

홍

芆

产

局

윽.

言

番

要

cs

疋

믕.

誩 